Vol. 1, No. 2, Juni 2021

\title{
PENGOLAHAN IKAN NILA MENJADI ABON IKAN NILA DI DESA DUMAN KECAMATAN LINGSAR LOMBOK BARAT
}

\author{
Akhmad Jufri \\ Fakultas Ekonomi dan Bisnis Universitas Mataram \\ jufi.akhmad@gmail.com \\ Muaidy Yasin \\ Fakultas Ekonomi dan Bisnis Universitas Mataram \\ muaidyyasin@unram.ac.id \\ Sahri \\ Fakultas Ekonomi dan Bisnis Universitas Mataram \\ sahri.feb@unram.ac.id \\ Mahyudin Nasir \\ Fakultas Ekonomi dan Bisnis Universitas Mataram \\ mahyuddin@gmail.com
}

\section{Article History: \\ Received: 21 Juni 2021 \\ Revised: 21 Juni 2021 \\ Accepted: 21 Juni 2021 \\ DOI: \\ 10.29303/abdimassangkabi ra.v1i2.38}

\begin{abstract}
Abstrak: Usaha budidaya pembesaran ikan nilai yang diakukan petani ikan di Desa Duman Kecamatan Lingsar terdiri dari usaha pembibitan dan pembesaran. Periode pembesaran selama 3 sampai 4 bulan menghasilkan produksi ikan nila yang tidak merata besarnya. Ukuran ikan nila yang disukai pembeli berukuran 3 sampai 5 ekor per $\mathrm{kg}$. Sedangkan ikan nila berukuran besar yaitu 1 sampai 2 ekor per $\mathrm{kg}$ kurang diminati pembeli. Ikan nila ukuran besar ini tidak menguntungkan untuk dipelihara sehingga terpaksa dijual walaupun dengan harga rendah. Karenanya untuk menjamin pemasaran dan mengurangi kerugian petani ikan dipandang perlu untuk melakukan pengabdian kepada masyarakat mengenai pembuatan abon ikan nila kepada ibu rumah tangga yang ada di Desa Duman. Pengabdian dilaksanakan dalam bentuk penyuluhan, focus discussion group (FGD), serta peraktik pembuatan abon. Hasil kegiatan pengabdian ditunjukan adanya pemahaman peserta memahami bahan dan proses pembuatan abon ikan nila, memahami perhitungan biaya dan harga jual, serta strategi pemasaran abon ikan nila.
\end{abstract}

Kata Kunci: pengolahan ikan nila, abon ikan nila 


\section{Pendahuluan}

Kecamatan Lingsar merupakan salah satu kecamatan yang memiliki sumberdaya air yang cukup banyak di Kabupaten Lombok Barat. Potensi sumberdaya air yang cukup banyak tersebut sangat mendukung berbagai kegiatan ekonomi yang dilakukan oleh masyarakat pada sektor pertanian, terutama sub sektor perikanan. Kegiatan ekonomi pada sub sektor perikanan yang banyak dilakukan oleh petani di Kecamatan Lingsar termasuk petani Desa Duman adalah usaha budidaya ikan air tawar. Jumlah produksi ikan air tawar di kabupaten Lombok Barat tahun 2020 sebanyak 10.216,44 ton dan Sebagian besar yaitu 7.639,10 ton atau 74, $77 \%$ merupakan produksi ikan nila ${ }^{10}$. Kecamatan Lingsar merupakan daerah penghasil produksi ikan nila terbesar dibandingkan kecamatan lainnya di Kabupaten Lombok Barat.

Usaha budidaya ikan air tawar yang diusahakan petani ikan Desa Duman terdiri dari dua jenis usaha, yaitu usaha pembibitan dan usaha pembesaran. Usaha pembesaran ikan dilakukan pada lahan sawah, dimana pada lahan sawah tersebut dibuat kolam ikan dengan kontruksi permanen, yaitu kolam dibuat dari bahan batu atau batako maupun dengan kontruksi semi permanen. Hasil observasi tim pengabdian menunjukkan bahwa kolam permanen untuk pembesaran ikan dibuat dengan ukuran rata-rata $100 \mathrm{~m}^{2}$ dengan kedalaman berkisar antara 125 cm sampai $175 \mathrm{~cm}$. Rata-rata diisi bibit ikan nila (Oreochromis niloticus) sebanyak $500 \mathrm{~kg}$. Jika ketinggian airnya sekitar $80 \mathrm{~cm}$ diisi bibit ikan nila sebanyak $350 \mathrm{~kg}$. Periode pemeliharaan selama 3 sampai 4 bulan untuk dipanen. Jumlah produksi ikan nila dengan bibit sebanyak $350 \mathrm{~kg}$ pada kolam ukuran 100 meter $^{2}$ adalah sekitar 1,5 ton sampai 1,7 ton, dan harga jual ditingkat petani sebesar Rp. 25.000,- per kg.

Pada masa pemeliharaan; yaitu 3 sampai 4 bulan; selalu terdapat bibit ikan nila yang pertumbuhannya lebih cepat dibandingkan dengan bibit ikan nila yang lain. Hal ini menyebabkan ikan nila tersebut menjadi lebih besar ukurannya pada saat panen, dan kurang diminati oleh pembeli yakni pedagang pengumpul. Ukuran ikan nila yang disenangi oleh pembeli adalah ukuran 3 sampai 5 ekor per kg atau seberat 200 sampai 300 geram per ekor.

Ikan nila yang lebih besar tersebut ukurannya rata-rata 1 sampai 2 ekor per kg dan ukuran ini merupakan ikan sortiran yang sulit dijual. Pada setiap panen rata-rata jumlah ikan nila ukuran besar yang sulit dijual sebanyak $4 \%$ sampai $5 \%$ dari total produksi. Hal ini sering kali terjadi, terutama pada saat musim hujan, yaitu pada bulan Pebruari sampai dengan Maret setiap tahun. Ikan nila sortiran yang ukuran besar tidak menguntungkan jika dipelihara, sebab pertambahan berat badannya tidak

\footnotetext{
${ }^{10}$ Badan Pusat Statistik, Kabupaten Lombok Barat Dalam Angka 2021, BPS Kabupaten Lombok Barat, Katalog 1102001.5201 (2021): 202
} 


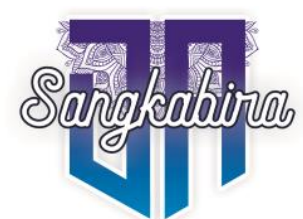

Vol. 1, No. 2, Juni 2021

sebanding dengan jumlah pakan yang diberikan. Karenanya, petani harus menjualnya walaupun dengan harga yang lebih murah, yaitu rata-rata Rp. 22.000,- per $\mathrm{kg}$. Kondisi ini juga dialami oleh petani ikan di desa lain di Kecamatan Lingsar Kabupaten Lombok Barat.

Permasalahan kesulitan pemasaran ikan sortiran ini tentu harus dicari cara untuk mengatasinya, dan salah cara mengatasinya adalah mengolah ikan sortiran yang ukuran besar tersebut menjadi abon ikan nila. Semestara dilain fihak keuarga petani dan masyarakat Desa Duman belum memiliki pengetahuan dan keterampilan abon ikan nila. Oleh karena itu dipandang perlu melakukan pengabdian kepada masyarakat dalam bentuk pelatihan pembuatan abon ikan nila bagi masyarakat khususnya keluarga petani ikan di Desa Duman Kecamatan Lingsar. Pelatihan ini dapat membantu petani ikan dalam memasarkan produksi ikan nila sortiran sekaligus menciptakan lapangan kerja baru yaitu usaha abon ikan nila.

Hasil Demontration Plot (DEMPOT) ibu PKK Desa Saribaye Kecamatan Lingsar menunjukkan bahwa ibu rumah tangga Desa Saribaye mampu mengolah abon ikan nila dengan cita rasa tinggi. Dalam $10 \mathrm{~kg}$ ikan nila diolah menjadi $4 \mathrm{~kg}$ abon ikan nila. Bilamana harga jual abon ikan nila Rp. 30.000,- per 100 gram, maka diperoleh keuntungan sebesar Rp 550.000,-11. Bila dibandingkan dengan pengolahan ikan patin, bahwa $50 \mathrm{~kg}$ ikan patin diolah menjadi abon ikan patin menghasikan laba kotor sebesar Rp 1.113.900,- dengan harga jual abon Rp 15.000,- per kemasan dengan berat 80 gram $^{12}$.

Tujuan kegiatan pengabdian ini adalah memberikan pengetahuan dan keterampilan mengolah ikan nila menjadi abon ikan nila. Demikian pula memberikan pengetahuan tentang perhitungan biaya dan pendapatan usaha abon ikan nila serta strategi pemasaran abon ikan nila. Kegiatan pengabdiankepada masyarakat ini diharapkan memberi manfaat kepada masyarakat terutama keluarga (isteri) petani ikan untuk terampil membuat abon ikan nila, mampu secara ekonomis menghitung biaya dan pendapatan usaha pemuatan abon ikan nila, dan dapat memasarkan produk abon ikan nila. Pada gilirannya diharapkan terciptanya usaha baru berupa berkembangnya sentra usaha abon ikan nila di Desa Duman Kecamatan lingsar kabupaten Lombok Barat.

\footnotetext{
${ }^{11}$ Suryani Embun, dkk, 2019, Pemberdayaan Ekonomi Masyarakat Desa Saribaye Melalui Pengolahan Abon Ikan Nila, Jurnal Abdi Insani LPPM Unram, Volume 6 nomor 3, Mataram (Desember 2019) : 401-408

12 Jasila dan Zahro, 2015, pembuatan abon ikan patin (pangasius hypophthalmus) di pradipta jaya food probolinggo, Samakia: Jurnal Ilmu Perikanan Volume 6, No. 1, Akademi Perikanan Ibrahimy, Situbondo Jawa Timur, (Februari 2015) : 20-35.
} 


\section{Metode}

Sasaran kegiatan pengabdian ini adalah ibu rumah tangga petani ikan dan anggota tim PKK Desa Duman Kecamatan Lingsar Kabupaten Lombok Barat. Peleksanaan pengabdian bertempat di Kantor Desa Duman dengan maksud untuk memotivasi peserta dan masyarakat Desa Duman lainnya. Metode pengabdian dilaksanakan dalam bentuk penyuluhan, FGD (focus group discussion) dan peraktik langsung semua proses pembuatan abon ikan nila dengan didampingi tim pengabdian.

Pengabdian dilaksanakan melalui berbagai tahapan mulai dari perencanaan, observasi, pelaksanaan kegiatan pengabdian dan pendampingan/evaluasi. Tahapan proses pengabdian sesuai bagan berikut:

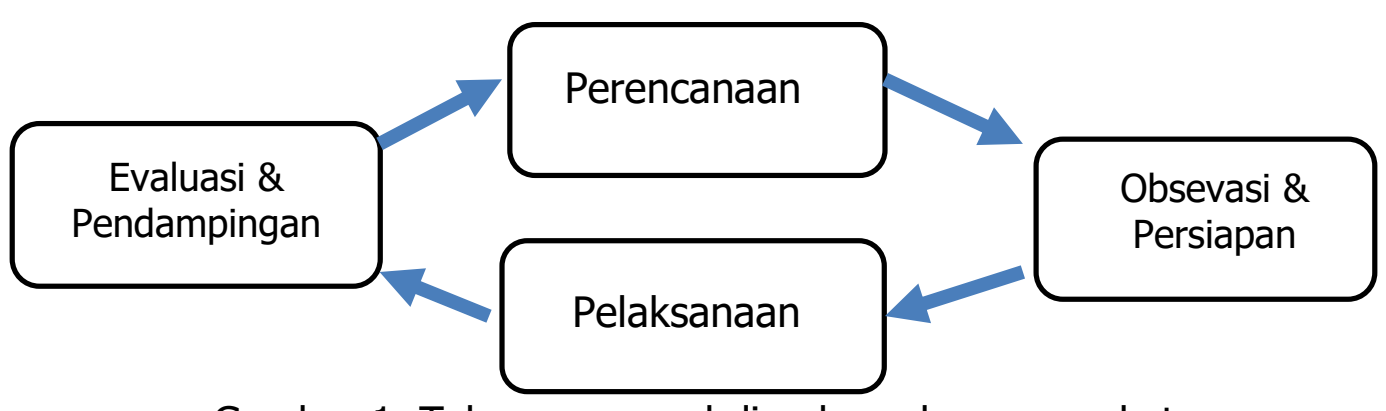

Gambar 1. Tahapan pengabdian kepada masyarakat

\section{Tahap Perencanaan :}

Kegiatan tahap perencanaan adalah melakukan kajian topik dan judul pengabdian kepada masyarakat sesuai payung pengabdian kepada masyarakat universitas mataram dan kelompok bidang ilmu yang ada di FEB Unram yaitu ilmu ekonomi dan studi pembangunan. Rincian aspek yang dikaji meliputi sasaran (subyek), obyek, permasalahan yang dihadapai, lokasi, manfaat/urgensi dan metode pelaksanaan pengabdian serta evaluasi/pendampingan. Demikian pula kajian terhadap rencana output/luaran uatama dan tambahan dari kegiatan pengabdian ini. Hasil kajian memutuskan melaksanakan pengabdian kepada masyarakat mengenai pengolahan ikan nila menjadi abon ikan nila di Desa Duman Kecamatan Lingsar Kabupaten Lombok Barat. Metode pelaksanaan pengabdian dilakukan dengan metode penyuluhan, FGD, peraktik langsung dan evaluasi/pendampingan.

\section{Tahap Observasi dan Persiapan :}

Melakukan peninjauan dan kajian lapangan ke lokasi sasaran pengabdian untuk memastikan sasaran (subyek), obyek, lokasi dan metode pelaksanaan pengabdian, serta memastikan mitra dalam pelaksanaan pengabdian. Dilakukan diskusi antara tim pengabdian dengan sasaran yaitu ibu rumah tangga petani ikan, dan mitra yaitu pengurus tim PKK Desa Duman. Kegiatan ini menyepakati keradiran peserta, waktu dan 


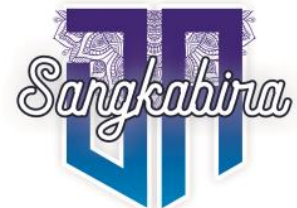

Vol. 1, No. 2, Juni 2021

tempat pelaksanaan pengabdian serta persiapan pengadaan bahan baku ikan nila, bumbu-bumbuan dan lainnya serta peralatan yang digunakan untuk peraktik pembuaatan abon ikan nila.

Tahap Pelaksanaan :

Melakukan kegiatan pengabdian sesuai kesepakatan pada saat observasi. Kegiatan pengabdian dihadiri oleh Ibu rumah tangga petani ikan, ibu rumah tangga lainnya, dan anggota tim PKK Desa Duman. Pelaksanaan pengabdian dilakukan dengan metode penyuluhan, FGD (focus group discussion), peraktik bersama semua proses pembuatan abon ikan nila. Materi penyuluhan dan FGD yang diberikan meliputi perhitungan biaya dan keuntungan persatuan produk abon ikan nila yang diperaktikkan, dan strategi pemasaran abon ikan nila.

\section{Tahap Evaluasi/pendampingan :}

Tahap ini melakukan evaluasi terhadap pemahaman dan keterampilan serta pengelolaan usaha abon ikan nila. Evaluasi awal dilakukan sebelum pelaksanaan praktik pembuatan abon, yaitu evaluasi pemahaman dan keterampilan pembuatan abon ikan nila. Evaluasi kedua pada saat pelaksanaan praktik pembuatan abon ikan nila, yaitu mengevaluasi ketepatan dan keterampilan melaksanakan semua proses pembuatan abon ikan nila dan pencatatan semua biaya pembuatan abon ikan nila. Evaluasi ketiga dilakukan terhadap kualitas abon ikan nila yang diperaktikkan, pembungkusan persatuan ukuran, kemampuan menghitung biaya dan kentungan persatuan (perbungkus) abon ikan nila serta pemahaman strategi pemasaran abon ikan nila uang diproduksi. Pendampingan dilakukan setelah selesai pelaksanaan pengabdian. Hal ini dilakukan untuk menjamin keberlangsungan pembuatan abon ikan nila sebagai usaha industri rumah tangga. Pendampingan dilakukan secara langsung dan memalui media komunikasi handphone. Kajian hasil evaluasi dan pendampingan dijadikan sebagai pertimbangan untuk melaksanakan pengabdian dan penelitian tahun berikutnya pada tinjauan aspek yang berbeda.

\section{Hasil Kegiatan Pengabdian}

1. Kehadiran Peserta

Kegiatan pengabdian kepada masyarakat ini diikuti oleh 24 (dua puluh empat ) orang peserta yang semuanya ibu rumah tangga dan ibu angota PKK Desa Duman Kecamatan Lingsar Kabupaten Lombok Barat. Pendidikan peserta mulai tamat Sekolah Lanjutan Pertama (SMP) sampai Perguruan Tinggi. Kehadiran peserta memenuhi target yang diharapkan sebanyak 24 orang peserta dan dihadiri oleh Ketua PKK Desa Duman (Muliati) Secara keseluruhan kegiatan penyluhan, FGD dan peratik pembuatan abon berjalan baik dan lancar. Seluruh peserta tidak ada yang meninggalkan tempat selama pelaksanaan pengabdian. Seluruh peserta 
antusias melakukan praktek pembuatan abon ikan nila. Mereka membagi diri melakukan seluruh tahapan pembuatan ikan mulai pembersihan sisik ikan, penyiapan peralatan, pengukusan, pemisahan daging ikan, pembuatan bumbu abon, pembumbuan, penggorengan, pemerasan abon dan pembungkusan.

2. Umpan Balik Peserta

Peserta atau sasaran pengabdian antusias mengikuti setiap tahapan materi penyuluhan dan asistensi peraktik pembuatan abon ikan nila. Hal ini terlihat dari adanya diskusi dan umpan balik antar perserta dengan pemberi materi dan pemandu peraktik pembuatan abon ikan nila, perhitungan biaya dan keuntungan serta strategi pemasaran produk abon ikan nila. Perserta cepat memahami dan mengikuti mengikuti pemandu setiap proses pembuatan abon ikan. Peserta lebih banyak bertanya terkait pemasaran produk abon ikan nila. Mereka nampak kurang percaya diri dalam memasarkan produk abon ikan nila yang akan diproduksi, dengan alasan rendahnya daya beli masyarakat desa duman dan kurang biasa mengkonsumsi abon ikan nila. Hal ini dijelaskan tim pengabdian melalui berbagai strategi pemasaran.

3. Pemahaman Peserta

Pemahaman peserta selama pemberian materi penyuluhan dan peraktik pembuatan abon ikan nila sebagai berikut :

a. Aspek Pengadaan Bahan Baku Ikan Nila

Peserta mendapat pemahaman mengenai pemilihan ikan nila sortiran ukuran besar sebagai bahan baku yang baik bagi pembuatan abon ikan nila. Demikian pula memahami bahwa ikan nila yang diberi pakan merk grobest akan menghasilkan serat daging yang baik dan tidak mengandung lendir sehingga kualitas abon ikan nila yang dihasilkan lebih baik bila dibandingkan dengan ikan nila yang diberi pakan merk lain.

b. Peraktik pembuatan abon ikan nila

Peserta mendapat pemahaman tahapan pengolahan ikan nila menjadi abon ikan nila mulai dari pembersihan sampai pengemasan sebagai berikut :

1) Peserta mendapat pemahaman mengenai cara pembersihan ikan, dimuali dari : (1) mematikan ikan yang hidup dengan cara memukul kepala ikan dengan kayu secara perlahan agar kepala ikan tidak hancur; (2) membersihkan sisik ikan mulai dari pangkal ekor keatas menuju dekat ingsang; (3) ikan yang sudah tanpa sisik dibelah dari bagian bawah tutup ingsang sampai dekat anus untuk selanjutnya dikeluarkan isi dalam perutnya. Setelah itu barulah dicuci untuk membuang semua kotoran yang melekat pada ikan nila tersebut.

2) Peserta mendapat pemahaman mengenai cara mengatur ikan dalam wadah untuk dikukus. Ikan diatur penempatannya secara merata agar kematangannya merata. Ikan tidak ditumpuk terlalu 


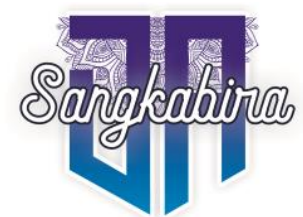

Vol. 1, No. 2, Juni 2021

banyak karena kalau banyak tumpukannya, ikan yang paling atas akan lama matangnya.

3) Peserta mendapat pemahaman bahwa ikan nila di kukus selama 15 menit. Pengukusan ikan nila tersebut ditambah dengan serai dan daun jeruk secukupnya dengan maksud untuk mengurangi bau amis. Sebelumnya peserta memperkirakan pengukusan dilakukan tanpa batasan waktu melainkan hanya melihat hasil pengukusan dimana ikan yang di kukus sudah matang dengan ciri-ciri lembek.

4) Peserta mendapat pemahaman mengenai pemisahan daging ikan nila yang sudah di kukus dari duri atau pemisahan daging dengan tulang ikan. Pemisahan dilakukan secara teliti agar tidak ada tulang yang masih bercampur dengan daging ikan untuk diperoses lebih lanjut. Dalam proses pemisahan ini tetap dijaga kebersihannya dengan menggunakan sarung tangan, baik dari bahan karet maupun plastik.

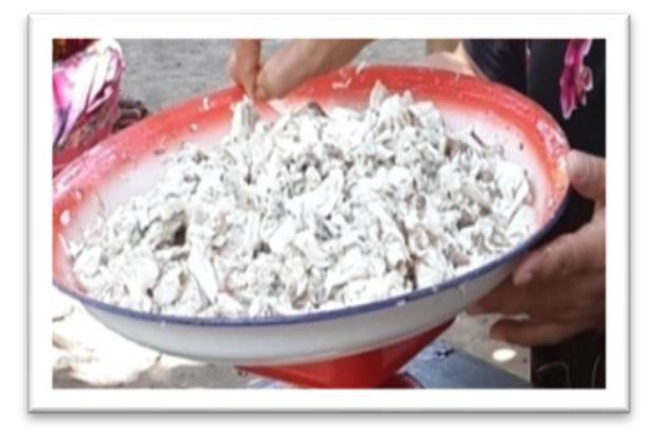

Gambar 1 : Pemisahan Daging Ikan Nila

5) Peserta mendapat pemahaman mengenai bahan bumbu-bumbuan yang digunakan untuk memberikan bumbu daging ikan yang akan diolah menjadi abon ikan. Demikian juga peserta mendapat pemahaman mengenai komposisi jumlah dan atau berat bahan bumbu yang akan digunakan serta cara pengolahan bumbu tersebut.
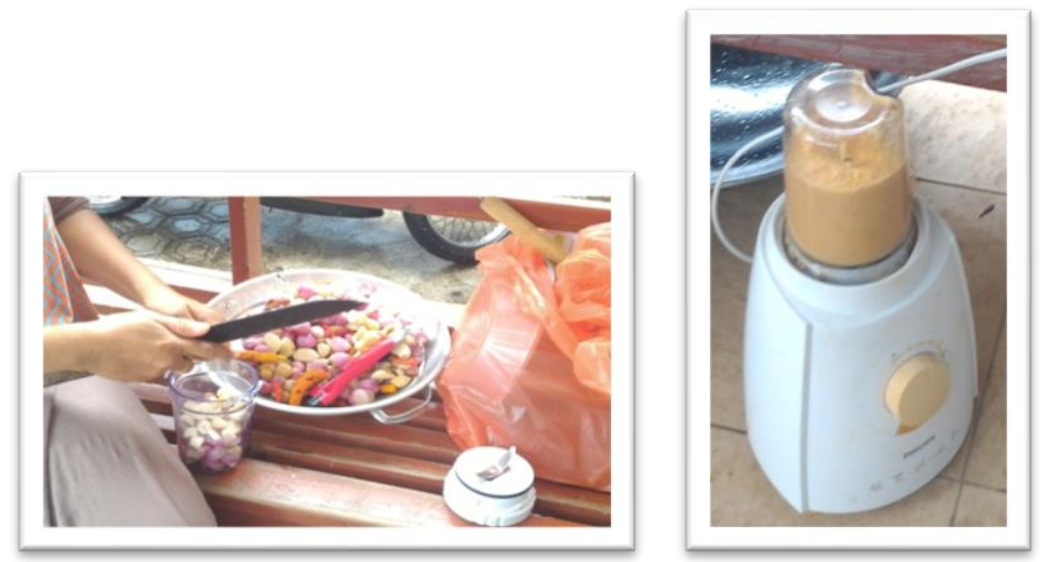

Gambar 2 : Bahan Bumbu Dan Pengolahan Bumbu Abon Daging Ikan Nila 
6) Peserta mendapat pemahaman cara memberikan bumbu daging ikan nila yang sudah dipisahkan dengan tulangnya. Pemberian bumbu dilakukan dengan cara menaburkan bumbu diatas daging ikan nila dan ditambah dengan daun salam dan daun jeruk, lalu diaduk secara perlahan sampai campuran terlihat merata. Bilamana di aduk tidak merata maka akan berpengaruh pada pemerataan tekstur maupun rasa abonnya nanti. Pengadukan bumbu menggunakan tangan yang telah dilengkapi dengan sarung tangan agar kebersihan tetap terjaga.
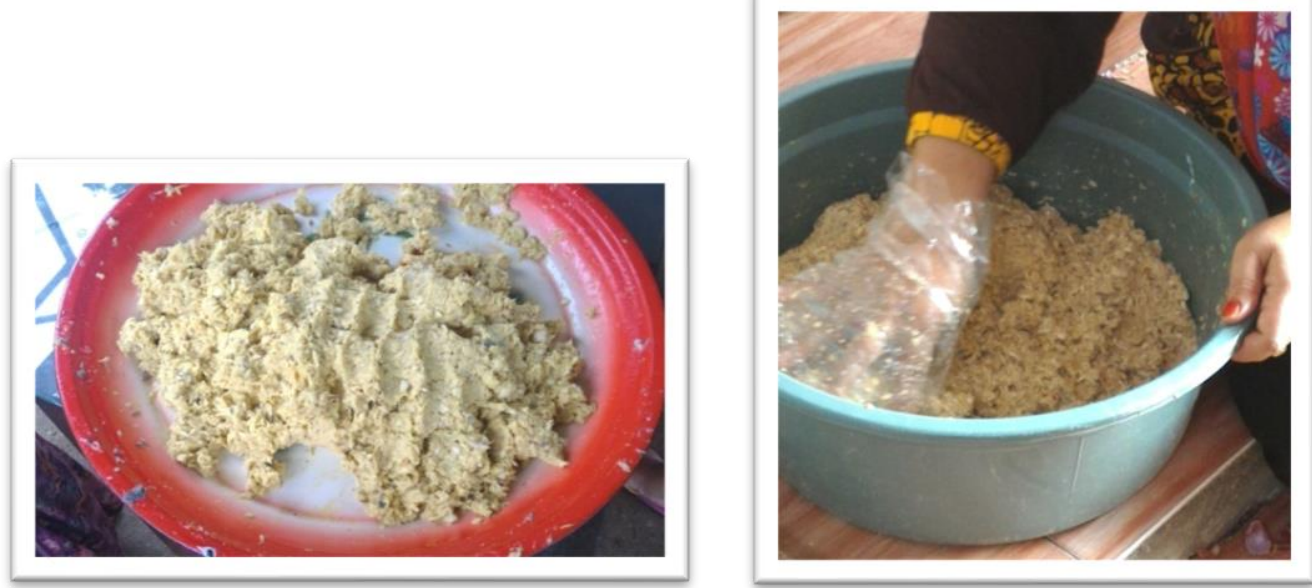

Gambar 3 : Pemberian Bumbu Daging Ikan Nila

7) Peserta mendapat pemahaman mengenai cara penggorengan daging ikan nila yang sudah dibumbu untuk diperoses menjadi abon ikan nila. Penggorengan dilakukan dengan wajan di atas api kompor gas dengan dengan besaran api yang tidak terlalu panas. Minyak goring yang digunakan sesuai dengan banyaknya daging ikan yang digoreng. Penggorengan dengan deep frying menggunakan perbandingan bahan dan minyak adalah 2:1. Selama penggorengan dalam waktu tertentu di aduk (di bolak balik) agar kematangan daging terlihat merata yang dicirikan dengan terjadinya perubahan warna dari warna keputihan menjadi kekuningan lalu berubah menjadi warna kuning kecoklatan.
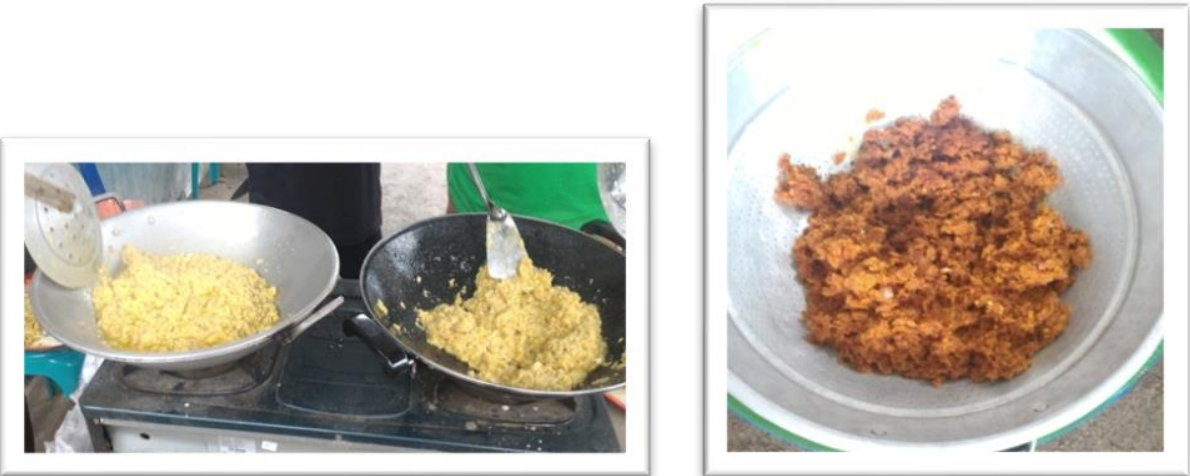


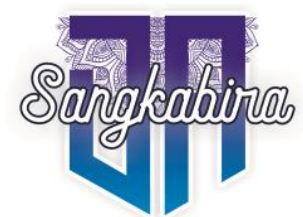

Vol. 1, No. 2, Juni 2021

Gambar 4 : Penggorengan Daging Ikan Nila Menjadi Abon Ikan Nila

8) Peserta memahami cara pengepresan abon ikan nila untuk menghilangkan kandungan minyak setelah digoreng. Abon ikan nila yang sudah ditiriskan dimasukkan ke alat pengepresan lalu dipres sampai minyaknya habis, kemudian ditaruh pada wadah yang sudah disiapkan untuk didinginkan sebelum dikemas. Pendinginan ini merupakan tahapan akhir pengolahan ikan nila menjadi abon ikan nila yang siap disajikan atau dikemas untuk siap dijual.
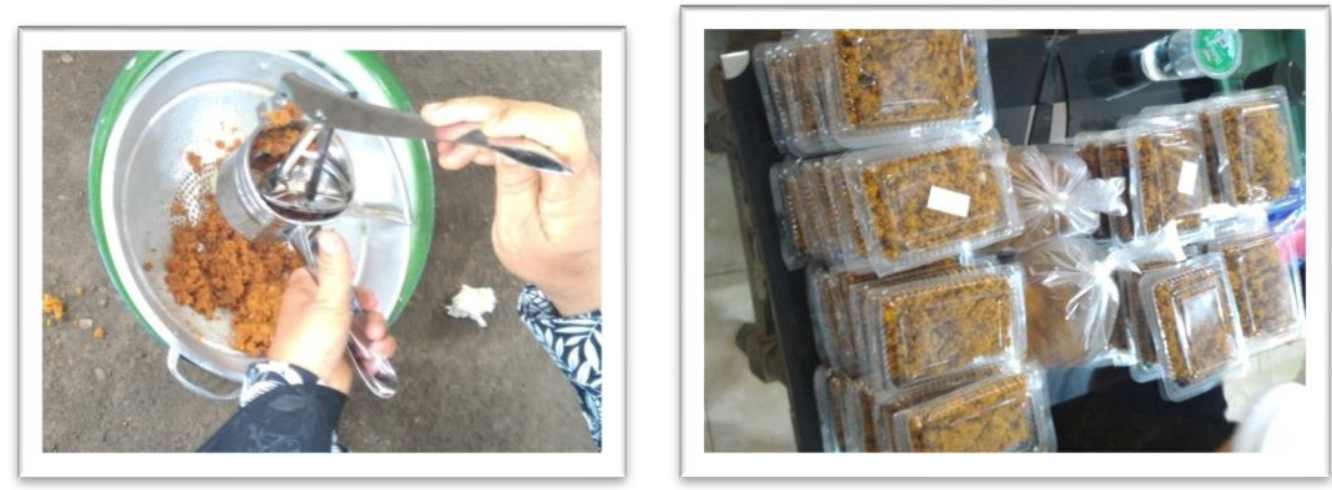

Gambar 5 : Pengepresan Abon Ikan Nila dan Abon Ikan Nila dalam kemasan

c. Perhitungan Biaya dan Harga Jual Abon Ikan Nila

Peserta dapat mengidentifikasi dan menghitung besarnya biaya pembuatan abon ikan nila dan dapat menentukan harga jual abon ikan nila tersebut.

1) Rincian biaya pembuatan abon ikan nila sebagai berikut:

a. Jumlah ikan nila yang digunakan dalam peraktek pembuatan abon ikan nila sebanyak 10 kilogram. Harga pembelian sebesar Rp 30.000,- per kilogram, sehingga biaya bahan baku ikan nila sortiran senilai Rp 300.000,-

b. Biaya pembelian bahan bumbu-bumbuan dan minyak goreng merk kunci mas sebesar Rp 75.000,--

c. Biaya bahan bakar gas seharga Rp 16.000,-.

d. Penyusutan peralatn perkali produksi sebesar Rp.10.000,-. Jadi total biaya produksi pembuatan abon ikan nila sebesar Rp 401.000,-

2) Berat abon ikan nila siap saji sebanyak 2,5 kilogram, sehingga harga pokok produksi (HPP) abon ikan nila diperhitungkan sebesar Rp 160.400,- per kilogram (Rp 401.000,- dibagi 2,5), atau HPP sebesar Rp 16.040,-per ons (per 100 gram).

3) Harga jual abon ikan nila merupakan HPP ditambah biaya pemasaran dan ditambah keuntungan yang diinginkan. Bilamana tidak ada biaya pemasaran yang dikeluarkan karena menjual di rumah dan keuntungan 
yang dinginkan 10\% dari HPP, maka harga jual abon ikan nila per ons sebesar Rp 18.000,-pembulatan dari Rp 17.644,- (HPP sebesar Rp 1.040,- ditambah keuntungan $10 \%=$ Rp 1.604,- ). Demikian pula bila dinginkan keuntungan sebesar 20\% dari HPP, maka harga jual abon ikan nila per ons sebesar Rp 19.245 dibulatkan menjadi Rp 19.500,atau per kilogram seharga Rp 195.000,-. Harga jual abon ikan nila ini dipandang masih jauh lebih rendah dibandingkan harga abon ikan laut seperti abon ikan patin yang dijual dengan harga sebesar Rp 25.000,per ons (per 100 gram)

d. Strategi Pemasaran

Peserta memahami strategi memasarkan abon ikan nila melalui strategi produk, strategi harga dan strategi saluran distribusi. Sebelumnya mereka berkeinginan menjual produk abon ikan nila di Desa Duman saja, yang berarti pemsarannya terbatas. Belum mengenal berbagai strategi pemasaran dalam memasarkan produk abon ikan nila ke pasar yang lebih luas.

\section{Diskusi}

Kegiatan penyuluhan, FGD, peraktik langsung pembuatan pembuatan abon ikan nila menunjukkan bahwa Peserta atau ibu rumah tangga memahami bahan baku ikan nila sortiran yang beratnya 1 sampai $2 \mathrm{~kg}$ er kg menjadi produk abon yang baik. Sebelumnya peserta memiliki pemahaman bahwa sembarang ukuran (berat) ikan nila dapat dijadikan abon ikan nila. Memang sembarang ukuran dapat dijadikan abon ikan, namun secara teknis produksi bahwa abon ikan yang dihasilkan tidak optimal. Untuk menghasilkan abon ikan nila yang optimal dipilih ikan nila ukuran besar dengan ukuran 1 sampai 2 ekor per kg.

Ibu rumah tangga sebagai peserta pengabdian masyarakat memahami dan dapat melakukan peraktik langsung dengan baik semua proses pembuatan abon ikan nilai mulai dari mematikan ikan nila, pembersihan sisik dan insang ikan, pengukusan, pemisahan daging dengan tulang ikan, pembumbuan, penggorengan dan pengepresan serta pembungkusan. Hasil evaluasi peraktik menunjukkan bahwa peserta mampu mengikuti tutorial tim pengabdian terhadap semua tahapan proses pembuatan abon ikan nila. Ini berarti ibu rumah tangga peserta pengabdian memiliki potensi keterampilan membuat abon ikan nila. Hal ini didorong oleh adanya keinginan kuat dari peserta untuk memiliki usaha abon ikan nila untuk menambah penghasilan keluarga. Keinginan kuat ini merupakan bagian dari aktualisasi diri peserta yang selaras dengan kebutuhan akan aktualisasi diri (Need for Self Actualization). Kebutuhan untuk mengungkapkan diri atau aktualisasi diri merupakan hierarki kebutuhan dasar manusia yang paling tinggi dalam Maslow. Aktualisasi diri dapat didefinisikan sebagai perkembangan dari individu yang paling tinggi, mengembangkan semua potensi yang ia miliki dan menjadi apa saja 


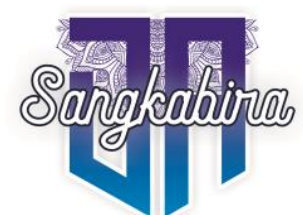

Vol. 1, No. 2, Juni 2021

menurut kemampuannya ${ }^{13}$. Pendapat Maslow menggarisbawahi bahwa aktualisasi diri itu tidak hanya berupa penciptaan kreasi atau karya bakat atau kemampuan khusus. Setiap orang bisa mengaktualisasikan dirinya, yakni dengan jalan melakukan yang terbaik atau bekerja sebaik-baiknya sesuai bidangnya masing-masing. Ia termotivasi untuk menjadi dirinya sendiri tanpa pengaruh atau tendensi apapun. Kecenderungan ini diwujudkan dengan adanya keinginan untuk menjadi yang terbaik, menjadi apa saja sesaui kemampuannya. Untuk itu bentuk aktualisasi diri berbeda pada setiap orang ${ }^{14}$. Keberadaan usaha abon ikan nila yang akan diusahakan peserta disamping dapat membantu penghasilan keluarga juga secara khusus dapat membantu kesulitan pemasaran ikan ukuran besar yang diusahan keluarga atau suami peserta pengabdian.

Hasil FGD menujukkan peserta memahami perhitungan biaya pembuatan dan keuntungan abon ikan nila. Sebelumnya peserta kurang terampil dalam menghitung seluruh komponen biaya pembuatan abon ikan nila. Belum tepat menghitung harga pokok penjualan abon ikan nila karena ada komponen biaya yang tidak dihitung seperti biaya bahan bakar gas dan biaya penyusutan peralatan. Demikian pula belum terampil menghitung berbagai alternatif persentase keuntungan yang akan ditentukan. Penentuan margin keuntungan yang besar akan mengakibatkan harga jual tinggi dan akan berpengaruh terhadap menurunnya permintaan.

Penyuluhan dan FGD memberikan hasil bahwa peserta memahami strategi pemasaran abon ikan nila secara luas. Terbuka wawasan bagi peserta untuk memasarkan abon ikan nila secara lebih luas ke luar Desa Duman dengan menerapkan berbagai strategi pemasaran. Kotler dan Armstrong menegaskan bauran pemasaran (marketing mix) adalah kumpulan alat pemasaran taktis terkendali yang dipadukan perusahaan untuk menghasilkan respon yang diinginkannya di pasar sasaran. Bauran pemasaran terdiri dari empat kelompok variabel yang disebut "empat P",yaitu: product (produk), price (harga), place (tempat) dan promotion (promosi) ${ }^{15}$. Bentuk strategi produk yang dilakukan adalah dengan memberikan rangsangan ini seperti pemberian kemasan yang menarik, pemasangan label atau merk abon dan selanjutnya dalam waktu tertentu kemasan tersebut dirubah guna menarik perhatian konsumen, serta informasi bahan dan kandungan abon ikan nila tersebut, misalnya "abon ikan nila asli 100\% daging ikan nila murni". Strategi harga dilakukan

\footnotetext{
${ }^{13}$ Duane Schultz,. Growth Psychology: Models of The Healthy Personality, terj. Yustinus, Psikologi Pertumbuhan, Yogyakarta: Kanisius, (1991) : 93

${ }^{14}$ Frank G. Goble, The Third Force:The Psychology of Abraham Maslow, terj. A.

Supratiknya, Mazhab Ketiga Psikologi Humanistik Abraham Maslow, Yogyakarta: Kanisius, (1995) : 29

${ }^{15}$ Kotler, P. and G. Armstrong. Dasar-dasar Pemasaran, Edisi Kesembilan.

Jakarta:Penerbit Indek (2004) :78.
} 
dengan membuat perbedaan harga pada tiap kemasan ikan abon nila dengan ukuran berat yang berbeda. Hal ini dimaksudkan agar konsumen memiliki pilihan permintaan sesuai kemampuan daya belinya. Strategi saluran distribusi dilakukan dengan menjual secara langsung kepada konsumen akhir (rumah tangga) maupun pedgang pengumpul lokal. Bilamana usaha abon ikan sudah berkembang dapat dijual melalui agenagen baik agen lokal, regional maupun nasional untuk selanjutnya diteruskan kepada konsumen akhir. Sedangkan strategi promosi dilakukan dengan cara bersosialisasi keliling kerumah-rumah warga di sekitar daerah tinggal untuk memperkenalkan produk abon ikan nila. Demikian pula selanjutnya dapat dilakukan dengan membagi kartu nama usaha, brosur, melalui sosial media seperti facebook, instagram, whatsApp dan media promosi lainnya. Sebagai pembanding, pengembangan usaha pengolahan abon ikan dilakukan dengan menerapkan strategi agresif atau stratesi SO (Strengths-Opportunities), yaitu meningkatkan penguasaan teknologi pengolahan abon untuk dapat meningkatkan kuantitas dan kualitas produk, meningkatkan modal untuk menambah kapasitas produksi, meningkatkan kulalitas tenaga kerja, dan meningkatkan promosi ${ }^{16}$. Penerapan strategi bauran pemasaran maupun stategi agresif oleh ibu rumah tangga peserta pengabdian diharapkan dapat mengembangkan usaha pengolahan abon ikan nila di Desa Duman Kecamatan Lingsar.

\section{KESIMPULAN}

Kesimpulan kegiatan pengolahan ikan nila menjadi abon ikan nila pada ibu rumah tangga di Desa Duman Kecamatan Lingsar adalah:

1. Ibu rumah tangga peserta pengabdian kepada masyarakat antusias mengikuti penyuluhan, FGD dan peraktik pembuatan abon ikan nila yang terlihat dari umpan balik antar perserta dengan pemberi materi dan pemandu praktik pembuatan abon ikan.

2. Peserta pengabdian masyarakat memahami pengadaan bahan baku ikan nila sortiran, dan terampil melakukan peraktik pembuatan abon ikan nila.

3. Peserta mampu menghitung biaya dan harga jual persatuan berat abon ikan nila dan memahami strategi pemasaran.

4. Kegiatan pengabdian ini dapat membuka wawasan atau mainsead peserta untuk membuat abon ikan nila sebagai usaha rumah tangga.

5. Rekomendasi :

6. Ibu rumah tanggga peserta pengabdian melakukan peraktik mandiri pembuatan abon ikan nila secara secara berkelompok.

\footnotetext{
${ }^{16}$ Aliyah, Gumilar danMaulina, Strategi Pengembangan Usaha Pengolahan Abon Ikan (Studi Kasus Rumah Abon Ikan Di Kota Bandung), Jurnal Perikanan Kelautan Vol. VI No.2 (Desember 2015) : 78-84
} 
Vol. 1, No. 2, Juni 2021

7. Mencoba memulai usaha pembuatan abon ikan nila dengan memasarkan kepada masyarakat sekitar Desa Duman.

8. Bermitra dengan petani ikan nila dalam pengadaan bahan baku ikan nila.

9. Perlu batuan peralatan dan pembinaan teknis dari dinas instansi terkait terutama dinas perindustrian Kabupaten Lombok Barat dalam rangka menumbuh kembangkan usaha pembuatan abon ikan nila.

\section{Pengakuan :}

Puji syukur kami panjatkan kepada Allah SWT, karena dengan rahmat dan karuniaNYA kegiatan pengabdian kepada masyarakat yang berjudul "Pengolahan Ikan Nila Menjadi Abon Ikan Nila Di Desa Duman Kecamatan Lingsar Lombok Barat" dapat dilaksanakan dengan baik dan lancar. Hasil kegiatan pengabdian ini dijadikan sebagai jurnal pengabdiaan dalam rangka memperkaya IPTEK khususnya dilingkungan Universitas Mataram. Kami tim pengabdian mengucapkan terimakasih kepada : 1) Bapak Rektor Universitas Mataram; 2) Bapak Dekan Fakultas ekonomi dan Bisnis Universitas Mataram; 3) Ketua Lembaga Penelitian dan Pengabdian Kepada Masyarakat (LPPM) Universitas Mataram; 4) Kepala Desa Desa dan ketua tim PKK Desa Duman Kecamatan Lingsar Kabupaten Lombok Barat; 5) Semua fihak yang terlibat membantu pelaksanaan pengabdia kepada masyarakat.

Semoga kegiatan pengabdian kepada masyarakat, laporan akhir dan jurnal pengabdian ini dapat memberikan manfaat kepada ibu rumah tangga, anggota tim PKK dan masyarakat Desa Dumam pada umumnya dalam mengembangkan usaha usaha pembuatan abon ikan nila serta civitas akademika Universitas Mataram dalam rangka pengembangan IPTEK. 


\section{Daftar Referensi}

Aliyah Rizkia, Gumilar Iwang dan Maulina Ine, Strategi Pengembangan Usaha Pengolahan Abon Ikan (Studi Kasus Rumah Abon Ikan Di Kota Bandung), Jurnal Perikanan Kelautan Vol. VI No.2 (Desember 2015) : 78-84

Badan Pusat Statistik, Kabupaten Lombok Barat Dalam Angka 2021, BPS Kabupaten Lombok Barat, Katalog 1102001.5201 (2021): 202

Duane Schultz,. Growth Psychology: Models of The Healthy Personality, terj. Yustinus, Psikologi Pertumbuhan, Yogyakarta: Kanisius, (1991) : 93

Frank G. Goble, The Third Force:The Psychology of Abraham Maslow, terj. A. Supratiknya, Mazhab Ketiga Psikologi Humanistik Abraham Maslow, Yogyakarta: Kanisius, (1995) : 29

Jasila Ismi dan Zahro Fadilatuz, 2015, pembuatan abon ikan patin (pangasius hypophthalmus) di pradipta jaya food probolinggo, Samakia: Jurnal Ilmu Perikanan Volume 6, No. 1, Akademi Perikanan Ibrahimy, Situbondo Jawa Timur, (Februari 2015) : 2035.

Kotler, P. and G. Armstrong. Dasar-dasar Pemasaran, Edisi Kesembilan. Jakarta:Penerbit Indek (2004) :78.

Suryani Embun, dkk, 2019, Pemberdayaan Ekonomi Masyarakat Desa Saribaye Melalui Pengolahan Abon Ikan Nila, Jurnal Abdi Insani LPPM Unram, Volume 6 nomor 3, Mataram（Desember 2019) : 401-408 